E-JURNAL EKONOMI DAN BISNIS UNIVERSITAS UDAYANA
Available online at https://ojs.unud.ac.id/index.php/EEB/index
Vol. 10 No. 10, October 2021, pages: 829-838
e-ISSN: 2337-3067

\title{
PENGARUH MODAL, TEKNOLOGI INFORMASI, DAN JAM KERJA TERHADAP PENDAPATAN UMKM SEKTOR PERDAGANGAN DI DENPASAR TIMUR
}

\author{
Ida Ayu Asri Mahayuni ${ }^{1}$ Anak Agung Bagus Putu Widanta ${ }^{2}$
}

Article history:

Submitted: 11 Mei 2021

Revised: 3 Juni 2021

Accepted: 12 Juni 2021

\section{Keywords:}

SMEs Income;

Capital;

Technology;

Working hours;

\section{Kata Kunci:}

Pendapatan UMKM;

Modal;

Teknologi;

Jam Kerja;

\section{Koresponding:}

Fakulas Ekonomi dan Bisnis

Universitas Udayana, Bali,

Indonesia

Email:

easrimahayuni11@gmail.com
Abstract

Capital is one of the factors that has an important role in the production process, because it is needed when an entrepreneur wants to establish a new company or to expand an existing business. Information technology can be maximally utilized to accelerate productivity in a business. With this tool, it is very easy for MSME actors to increase productivity which will ultimately affect income levels. The longer the working hours of a trader to run his business, the more customers he has. The increase in the number of customers, both those who shop directly at the store or who shop via online media, is one of the factors that can affect the income earned. This study aims to determine the simultaneous and partial effect of capital, information technology, and working hours on the income of SMEs in the trading sector in East Denpasar District by using a non-probability sampling technique, namely purposive sampling using the Slovin formula so that obtained as many as 93 samples. The results showed that simultaneously all independent variables have a significant effect on the dependent variable. Partially the variables of capital, information technology, and working hours have a positive and significant effect on the income of MSME players in the trading sector in East Denpasar District.

Abstrak
Modal merupakan salah satu faktor yang memiliki peran penting
dalam proses produksi, karena diperlukan ketika pengusaha hendak
mendirikan perusahaan baru atau untuk memperluas sebuah usaha yang
sudah ada. Teknologi inforfamasi dapat dimanfaatkan dengan maksimal
untuk mempercepat produktivitas dalam suatu usaha. Dengan adanya alat
tersebut, sangat mudah para pelaku UMKM untuk meningkatkan
produktivitas yang pada akhirnya akan mempengaruhi tingkat pendapatan.
Semakin lama jam kerja pedagang menjalani usahanya, maka semakin
banyak jumlah pelanggan yang dimiliki. Peningkatan jumlah pelanggan,
baik yang berbelanja langsung ke toko ataupun yang berbelanja lewat media
online merupakan salah satu faktor yang dapat mempengaruhi pendapatan
yang diperoleh. Penelitian ini bertujuan untuk mengetahui pengaruh
simultan dan parsial modal, teknologi informasi, dan jam kerja terhadap
pendapatan pelaku UMKM sektor perdagangan di Kecamatan Denpasar
Timur dengan menggunakan teknik non-probability sampling, yaitu
purposieve sampling dengan menggunakan rumus Slovin sehingga didapat
sebanyak 93 sampel. Hasil penelitian menunjukkan secara simultan seluruh
variabel bebas berpengaruh signifikan terhadap variabel terikat. Secara
parsial variabel modal, teknologi informasi, dan jam kerja berpengaruh
positif dan signifikan terhadap pendapatan pelaku UMKM sektor
perdagangan di Kecamatan Denpasar Timur.




\section{PENDAHULUAN}

Usaha Mikro Kecil dan Menengah (UMKM) dapat mengurangi tingkat kesenjangan pendapatan, dan membantu dalam pengentasan kemiskinan serta menyerap tenaga kerja, sehingga menjadi salah satu prioritas yang membantu pengembangan ekonomi nasional. Menurut Kurniawan (2011), pengembangan UMKM dapat memberikan kontribusi yang signifikan dalam mempercepat struktual dan akan memperluas basis ekonomi yaitu meningkatkan perekonomian daerah dan ketahanan ekonomi nasional. UMKM memiliki peran penting dalam kegiatan ekonomi di Indonesia. Kemampuan ekonomi di masa mendatang akan bergantung pada kemampuan UMKM dalam mengembangkan diri.

Perkembangan UMKM yang cukup pesat terdapat di Kota Denpasar, yang merupakan salah satu daerah di Provinsi Bali. Berdasarkan data dari Dinas Usaha Kecil dan Menengah Kota Denpasar (2020) diketahui bahwa daerah sebaran pelaku UMKM terendah Denpasar Timur yaitu sebanyak 3.869 unit. Dari jumlah tersebut menunjukkan bahwa perkembangan UMKM di kota Denpasar telah tumbuh dan berkembang dengan baik di masing-masing kecamatan di Kota Denpasar. UMKM sektor perdagangan adalah perusahaan atau usaha yang dilakukan dengan penjualan kembali (tanpa perubahan teknis) barang baru atau barang bekas. Aktivitas perdagangan yang semakin meningkat menyebabkan semakin tingginya persingan antar pelaku UMKM dalam memperoleh pendapatan (Kurniawan, 2016). Dalam upaya meningkatkan pendapatannya pelaku UMKM akan melakukan beberapa strategi pendekatan kepada pelanggannya, berupa pendekatan secara konvensional ataupun menggunakan media elektronik.

Pada era revolusi industry 4.0 saat ini pelaku UMKM lebih memanfaatkan media internet yang terhubung dengan E-commerce. Salah satu keuntungan yang akan didapatkan melalui penggunaan E-commerce bagi UMKM adalah memperluas pangsa pasar sehingga dapat menjangkau ke pasar internasional. Menurut Widyanita (dalam Surawiguna, 2010) yang menjelaskan bahwa $E$ commerce sebagai salah satu jenis dari mekanisme bisnis secara elektronik yang berfokus pada transaksi bisnis berbasis individu dengan menggunakan internet sebagai media pertukaran barang atau jasa. Rainer dan Cigielski (2011) mengemukakan bahwa E-commerce menggambarkan proses membeli, menjual, mentransfer, atau bertukar produk, jasa, atau informasi melalui jaringan komputer, termasuk internet. E-commerce juga memungkinkan perusahaan untuk memperluas jangkauan bisnis mereka. Salah satu manfaat utama dari E-commerce adalah akses ke dan dari pasar global. Ecommerce menghilangkan hambatan geografis beberapa perusahaan yang ingin melakukan perdagangan global.

UMKM saat ini bersaing dalam menyediakan layanan online baik sebagai pengganti atau sebagai tambahan untuk layanan offlinenya yang tradisional (Pujari, 2004). Agar tetap mampu berkompetitif, UMKM harus menggunakan Teknologi Informasi (TI) dalam tingkatan yang sesuai dengan ukuran perusahaan. Pendidikan bukan saja akan melahirkan sumber daya manusia (SDM) berkualitas, memiliki pengetahuan dan keterampilan serta menguasai teknologi, tetapi juga dapat menumbuhkan iklim bisnis yang sehat dan kondusif bagi pertumbuhan ekonomi (Artana Yasa, 2015).

Semakin lama jam kerja pedagang dalam menjalani usahanya, maka pedagang akan memiliki semakin banyak jumlah pelanggan. Dengan adanya jumlah pelanggan yang meningkat akan berpengaruh terhadap pendapatan yang diperoleh. Pada hakikatnya tujuan bisnis adalah untuk menciptakan dan mempertahankan para pelanggan (Reinartz, 2000). Lamanya jam kerja dalam setiap minggu bagi setiap orang tidak sama, hal ini dikarenakan beberapa hal diantaranya alasan ekonomi. Semakin banyak jam kerja yang dikorbankan maka produktivitas akan semakin banyak, dan

Pengaruh Modal, Teknologi Informasi, dan Jam Kerja Terhadap Pendapatan Umkm Sektor Perdagangan di 
pendapatan yang didapat akan semakin meningkat, hal ini dapat dikatakan bahwa jam kerja berpengaruh positif dan signifikan terhadap pendapatan (Wiyasa, 2017).

Modal adalah salah satu faktor yang berperan dalam proses produksi, karena tanpa modal yang cukup maka akan berpengaruh terhadap kelancaran usaha, sehingga akan mempengaruhi pendapatan yang diperoleh. Sesuai dengan karakteristik skala usahanya, UMKM tidak memerlukan modal dalam jumlah yang terlalu besar (Ashari, 2006). Faktor-faktor lain yang mendukung produksi UMKM adalah modal dan teknologi. Modal usaha merupakan salah satu faktor produksi yang mempunyai peranan cukup vital dalam proses produksi sehingga modal usaha dapat dikatakan berpengaruh positif terhadap pendapatan (Rimayanti, 2019). Pengembangan teknologi UMKM dipengaruhi banyak faktor, seperti kemampuan sumber daya manusia dalam mengembangkan teknologi, adanya modal untuk mengembangkan teknologi, peran dari lembaga-lembaga penelitian untuk mengembangkan teknologi dan kebijakan fiscal moneter (Suharyadi, 2004).

Teori dasar yang digunakan dalam penelitian ini adalah teori pendapatan. Dalam teori mikro, pendapatan dapat dihitung dengan cara mengalikan antar harga dengan jumlah kuantitas yang terjual, sedangkan pendapatan rata-rata yaitu jumlah pendapatan total yang dibagi dengan jumlah produk. Pendapatan adalah seluruh hasil yang diterima dari pembayaran atas penggunaan faktor-faktor produksi yang dimiliki, baik berupa uang maupun barang yang berasal dari pihak lain maupun dari hasil industri yang dinilai atas dasar sejumlah uang dari harta yang berlaku saat itu (Sukirno, 2007: 43). Pendapatan menunjukkan jumlah seluruh uang yang diterima oleh seseorang atau rumah tangga selama jangka waktu tertentu (biasanya satu tahun) (Samuelson, 2008: 258).

Berdasarkan permasalahan yang telah diuraikan, maka hipotesis yang dalam penelitian ini adalah: H1: Modal, teknologi informasi dan jam kerja secara simultan berpengaruh terhadap pendapatan pelaku UMKM sektor perdagangan di Kecamatan Denpasar Timur; H2: Modal, teknologi informasi dan jam kerja secara parsial berpengaruh positif dan signifikan terhadap pendapatan pelaku UMKM sektor perdagangan di Kecamatan Denpasar Timur.

\section{METODE PENELITIAN}

Penelitian ini menggunakan metode kuantitatif yang berbentuk asosiatif. Metode penelitian kuantitatif adalah metode penelitian yang digunakan untuk meneliti pada populasi atau sampel tertentu yang bertujuan untuk menguji hipotesis yang telah ditetapkan dengan menggunakan data yang telah dikumpulkan. Penelitian yang dilakukan berbentuk asosiatif yaitu penelitian yang bertujuan untuk menguji hipotesis hubungan antara dua variabel atau lebih (Sugiyono, 2017). Penelitian ini dilakukan di Kecamatan Denpasar Timur, Kota Denpasar, Provinsi Bali. Lokasi ini diambil karena diantara kecamatan yang lainnya UMKM Denpasar Timur merupakan UMKM yang menggunakan teknologi dalam berjualan. Obyek dalam penelitian ini adalah pelaku UMKM sektor perdagangan Kecamatan Denpasar Timur yang di dukung oleh variabel modal, teknologi informasi, dan jam kerja. Berdasarkan jenis datanya, data kuantitatif dalam penelitian ini adalah banyaknya Pelaku UMKM sektor perdagangan Kecamatan Denpasar Timur, dan data kualitatif dalam penelitian ini adalah informasi terkait tentang modal, teknologi informasi, dan jam kerja yang mempengaruhi pendapatan pelaku UMKM sektor perdagangan Kecamatan Denpasar Timur.

Data dalam penelitian diperoleh melalui Dinas Koperasi dan UKM Kota Denpasar serta literatur lain yang mendukung mengenai objek penelitian (data sekunder), dan melalui penyebaran

Pengaruh Modal, Teknologi Informasi, dan Jam Kerja Terhadap Pendapatan Umkm Sektor Perdagangan di 
kuisioner dengan mencantumkan daftar pertanyaan yang telah disiapkan terlebih dahulu (data primer). Dalam penelitian ini populasi yang digunakan adalah jumlah Pelaku UMKM Sektor Perdagangan di Kecamatan Denpasar Timur yaitu sebanyak 1.420 unit dan diperoleh sampel sebanyak 93 orang yang ditentukan dengan menggunakan metode probability sampling dan non-probability sampling. Adapun metode pengumpulan data yang digunakan yaitu dengan melakukan observasi, menyebarkan kuesioner, dan wawancara mendalam kepada responden. Teknik analisis data yang digunakan yaitu analisis regresi linier berganda.

\section{HASIL DAN PEMBAHASAN}

Berdasarkan jenis kelamin, dari 93 responden pelaku UMKM di Kecamatan Denpasar Timur proporsi berdasarkan jenis kelamin terdapat perbedaan antara laki- laki dan perempuan. Jenis kelamin laki - laki memiliki proporsi sejumlah 49 orang atau $41,9 \%$ persen dan jenis kelamin perempuan memiliki proporsi sejumlah 54 orang atau 58,1 persen. Perbedaan jumlah responden berdasarkan jenis kelaminnya menunjukkan bahwa, pelaku UMKM perempuan lebih banyak dibandingkan dengan pelaku UMKM laki - laki. Berdasarkan usia, secara umum usia pelaku UMKM terbanyak yang aktif dalam menjalani usaha terdapat pada rentangumur 45 - 49 yaitu sebanyak 19 orang dengan persentase $19,5 \%$. Berdasarkan pendidikan terakhir yang ditamatkan, tingkat pendidikan terakhir yang ditamatkan oleh responden terbanyak berada pada tingkat PT (Perguruan Tinggi) yaitu sebanyak 55 orang dengan persentase 59,2\%. Hal ini menunjukkan bahwa pendidikan responden sudah baik karena mampu melaksanakan program pemerintah yaitu wajib belajar 12 tahun.

\section{Tabel 1}

Hasil Uji Analisis Regresi Linier Berganda

\begin{tabular}{|c|c|c|c|c|c|c|}
\hline & & \multicolumn{2}{|c|}{$\begin{array}{c}\text { Unstandardized } \\
\text { Coefficients }\end{array}$} & \multirow{2}{*}{$\begin{array}{c}\text { Standardized } \\
\text { Coefficients } \\
\text { Beta } \\
\end{array}$} & \multirow[b]{2}{*}{$\mathrm{t}$} & \multirow[b]{2}{*}{ Sig. } \\
\hline \multicolumn{2}{|c|}{ Model } & $\mathrm{B}$ & Std. Error & & & \\
\hline \multirow[t]{4}{*}{1} & (Constant) & 8.934 & 1.038 & & 8.608 & .000 \\
\hline & Modal & .321 & .073 & .350 & 4.404 & .000 \\
\hline & Teknologi informasi & .370 & .101 & .277 & 3.673 & .000 \\
\hline & Jam Kerja & .320 & .062 & .396 & 5.148 & .000 \\
\hline
\end{tabular}

a. Dependent Variable: Pendapatan

Sumber : Data Diolah, 2021

Tabel 2

Hasil Uji Normalitas

One-Sample Kolmogorov-Smirnov Test

\begin{tabular}{cc} 
& Unstandardized Residual \\
\hline $\mathrm{N}$ & 93 \\
Kolmogorov-Smirnov Z & .661 \\
Asymp. Sig. (2-tailed) & .775 \\
\hline
\end{tabular}

a. Test distribution is Normal.

b. Calculated from data.

Sumber : Data Diolah (2021)

Pengaruh Modal, Teknologi Informasi, dan Jam Kerja Terhadap Pendapatan Umkm Sektor Perdagangan di Denpasar Timur, Ida Ayu Asri Mahayuni dan Anak Agung Bagus Putu Widanta 
Uji normalitas', diperoleh nilai Asymp.Sig (2-tailed) sebesar 0,775 atau lebih besar $\alpha=0,05$ sehingga dapat disimpulkan bahwa residual dalam penelitian ini telah berdistribusi normal. Oleh karena residual model berdistribusi normal, maka model layak digunakan untuk menganalisis lebih lanjut.

Uji Multikolinearitas, diperoleh nilai tolerance untuk Modal $\left(\mathrm{X}_{1}\right)$ 0,835 $>0,10$, Teknologi Informasi $\left(X_{2}\right)$ 0,930 > 0,10, Jam Kerja $\left(X_{3}\right)$ 0,894 > 0,10, dan nilai VIF untuk Modal $\left(X_{1}\right) 1.198<10$, Teknologi Informasi $\left(\mathrm{X}_{2}\right) 1,076<10$, Jam Kerja $\left(\mathrm{X}_{3}\right) 1,118<10$, sehingga dapat disimpulkan bahwa tidak terdapat multikolinearitas yang antar variabel bebas dalam penelitian ini .

Tabel 3

Hasil Uji Multikolinearitas

\begin{tabular}{|c|c|c|c|c|c|c|c|c|}
\hline \multicolumn{9}{|c|}{ Coefficients $^{\mathrm{a}}$} \\
\hline \multicolumn{2}{|c|}{ Model } & \multicolumn{2}{|c|}{$\begin{array}{l}\text { Unstandardized } \\
\text { Coefficients }\end{array}$} & \multirow{2}{*}{$\begin{array}{c}\text { Standardi } \\
\text { zed } \\
\text { Coefficien } \\
\text { ts } \\
\text { Beta } \\
\end{array}$} & \multirow[t]{2}{*}{$\mathrm{T}$} & \multirow[t]{2}{*}{ Sig. } & \multicolumn{2}{|c|}{ Collinearity Statistics } \\
\hline \multirow{5}{*}{1} & & & & & & & & \\
\hline & (Constant) & 8.934 & 1.038 & & 8.608 & .000 & & \\
\hline & Modal & .321 & .073 & .350 & 4.404 & .000 & .835 & 1.198 \\
\hline & Teknologi informasi & .370 & .101 & .277 & 3.673 & .000 & .930 & 1.076 \\
\hline & Jam Kerja & .320 & .062 & .396 & 5.148 & .000 & .894 & 1.118 \\
\hline
\end{tabular}

a. Dependent Variable: Pendapatan

Sumber : Data Diolah (2021)

Uji Heteroskedastisitas, diperoleh nilai signifikansi Uji Glejser untuk Modal $\left(\mathrm{X}_{1}\right)$ 0,288 > 0,05, Teknologi Informasi $\left(\mathrm{X}_{2}\right)$ 0,826 > 0,05, Jam Kerja $\left(\mathrm{X}_{3}\right)$ 0,668 > 0,05, sehingga dapat disimpulkan bahwa variabel bebas secara statistik tidak mempengaruhi variabel terikat, nilai absolute tidak terjadi heteroskedastisitas .

Tabel 4

Hasil Uji Heteroskedastisitas

\begin{tabular}{|c|c|c|c|c|c|c|}
\hline \multicolumn{7}{|c|}{ Coefficients $^{\mathrm{a}}$} \\
\hline \multicolumn{2}{|c|}{ Model } & \multicolumn{2}{|c|}{$\begin{array}{c}\text { Unstandardized } \\
\text { Coefficients }\end{array}$} & \multirow{2}{*}{$\begin{array}{c}\text { Standardi } \\
\text { zed } \\
\text { Coefficien } \\
\text { ts } \\
\text { Beta } \\
\end{array}$} & \multirow[t]{2}{*}{$\mathrm{t}$} & \multirow[t]{2}{*}{ Sig. } \\
\hline & & B & Std. Error & & & \\
\hline \multirow[t]{4}{*}{1} & (Constant) & -311.761 & 242.556 & & -1.285 & .202 \\
\hline & Modal & 18.177 & 17.019 & .120 & 1.068 & .288 \\
\hline & Teknologi informasi & 5.207 & 23.559 & .024 & .221 & .826 \\
\hline & Jam Kerja & 6.253 & 14.537 & .047 & .430 & .668 \\
\hline
\end{tabular}

a. Dependent Variable: Abs_RES

Sumber : Data Diolah (2021)

Pengaruh Modal, Teknologi Informasi, dan Jam Kerja Terhadap Pendapatan Umkm Sektor Perdagangan di 


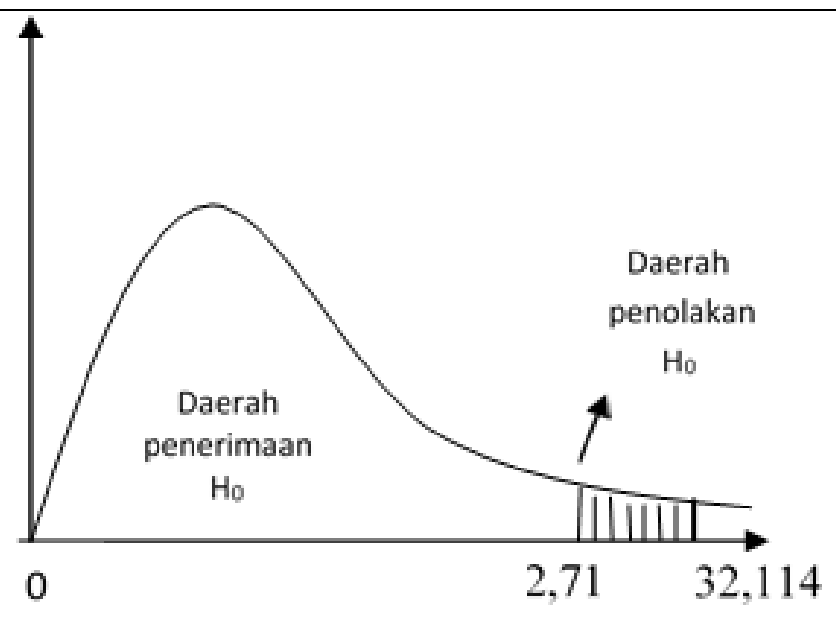

Gambar 1.

\section{Daerah Penerimaan dan Penolakan $\mathrm{H}_{0}$ dengan Uji F}

Berdasarkan hasil uji diperoleh nilai Fhitung yaitu sebesar 32,114 lebih besar dari Ftabel yaitu sebesar 2,71 dan tingkat signifikansi sebesar 0,000 lebih kecil dari 0,05, Hal tersebut berarti bahwa modal, teknologi informasi, dan jam kerja secara simultan berpengaruh dan signifikan terhadap pendapatan pelaku UMKM sektor perdagangan di Kecamatan Denpasar Timur. Besarnya pengaruh ketiga variabel bebas dapat diketahui dengan koefesien determinasi atau Adjusted $R$ square $\left(\mathrm{R}^{2}\right)=$ 0,493 mempunyai arti bahwa sebesar 49,3\% pendapatan pelaku UMKM sektor perdagangan di Kecamatan Denpasar Timur dipengaruhi oleh modal, teknologi informasi, dan jam kerka sedangkan sisanya 50,7\% dipengaruhi oleh faktor lain yang tidak dimasukan dalam variabel penelitian.

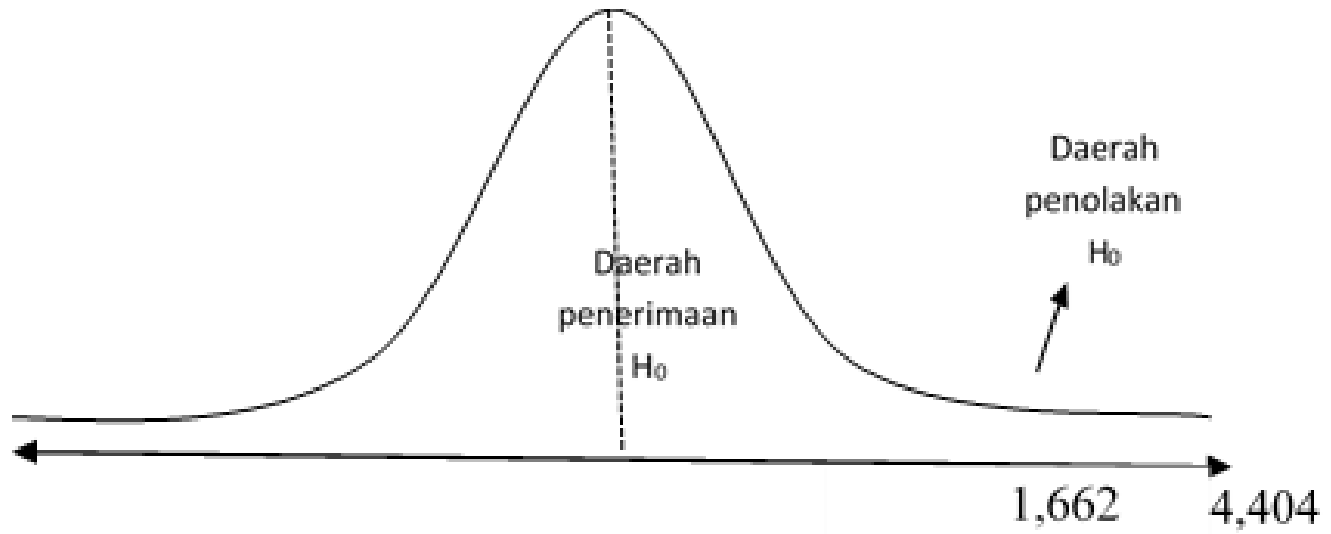

Gambar 2.

Daerah Penerimaan dan Penolakan $H_{0}$ Dengan Uji t untuk Variabel Modal $\left(\mathbf{X}_{1}\right)$

Berdasarkan hasil pengujian diperoleh nilai $t_{\text {hitung }} 4,404>t_{\text {tabel }}$ 1,662 dan tingkat signifikansi sebesar $0,000<0,05$ berarti bahwa variabel modal secara parsial berpengaruh positif dan signifikan terhadap pendapatan pelaku UMKM sektor perdagangan di Kecamatan Denpasar Timur. Nilai $\beta_{1}$ sebesar 0,321 menunjukkan bahwa jika modal $\left(\mathrm{X}_{1}\right)$ meningkat sebesar 1 rupiah dan variabel bebas lainnya dianggap konstan maka pendapatan pelaku UMKM (Y) akan bertambah sebesar 0,321 rupiah.

Pengaruh Modal, Teknologi Informasi, dan Jam Kerja Terhadap Pendapatan Umkm Sektor Perdagangan di Denpasar Timur, Ida Ayu Asri Mahayuni dan Anak Agung Bagus Putu Widanta 
Hasil penelitian ini dipekuat oleh hasil penelitian menurut Ryanto (2001) dalam Utari (2014) , yang menyatakan bahwa semakin besar modal perusahaan maka akan berpengaruh positif terhadap pendapatan yang diterima. Adapun hubungannya dengan penelitian ini bahwa modal sama-sama berpengaruh positif terhadap pendapatan UMKM.

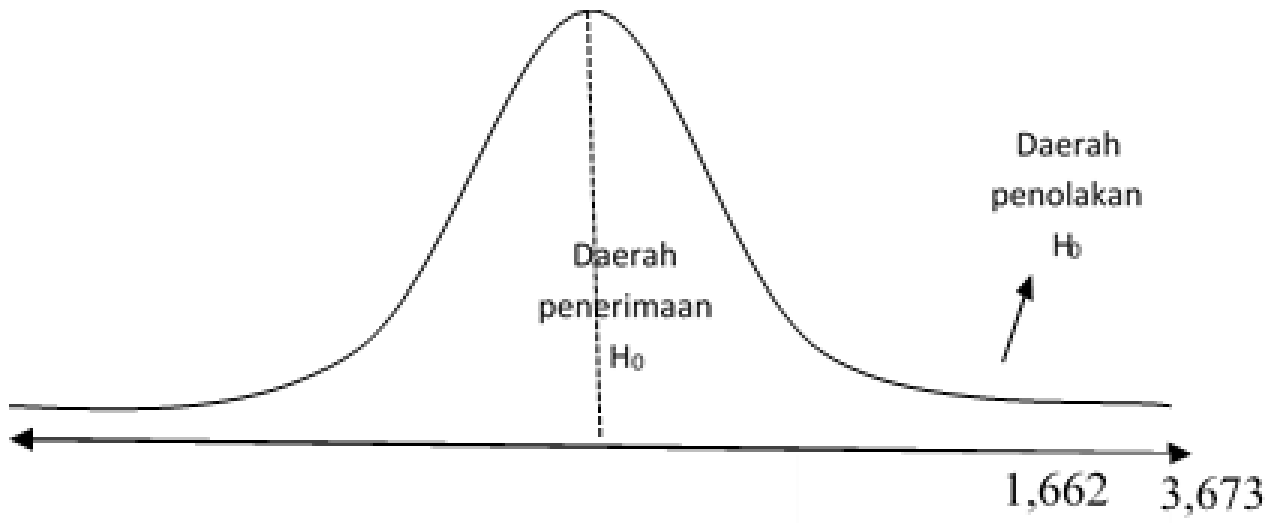

Gambar 3.

Daerah Penerimaan dan Penolakan $H_{0}$ Dengan Uji t untuk Variabel Teknologi Informasi $\left(\mathrm{X}_{2}\right)$

Berdasarkan hasil pengujian diperoleh nilai $\mathrm{t}_{\text {hitung }} 3,673>1,662$ dan tingkat signifikansi sebesar $0,000<0,05$ berarti bahwa teknologi informasi secara parsial berpengaruh positif dan signifikan terhadap pendapatan pelaku UMKM sektor perdagangan di Kecamatan Denpasar Timur. Nilai $\beta 2$ sebesar 0,370 menunjukkan bahwa menunjukkan bahwa pendapatan rata-rata UMKM yang menggunakan Teknologi Informasi lebih tinggi 0,370 rupiah dari pada UMKM yang tidak menggunakan Teknologi Informasi dan variabel bebas lainnya dianggap konstan. Dalam penelitian sebelumnya menyatakan bahwa teknologi berpengaruh positif terhadap tingkat pendapat yang akan diterima UMKM. Artinya semakin modern teknologi yang digunakan, maka pendapatan UMKM yang diterima juga akan semakin meningkat. Adapun hubungannya dengan penelitian ini teknologi samasama berpengaruh positif terhadap pendapatan UMKM. (Suparmoko dan Irawan, 2003)

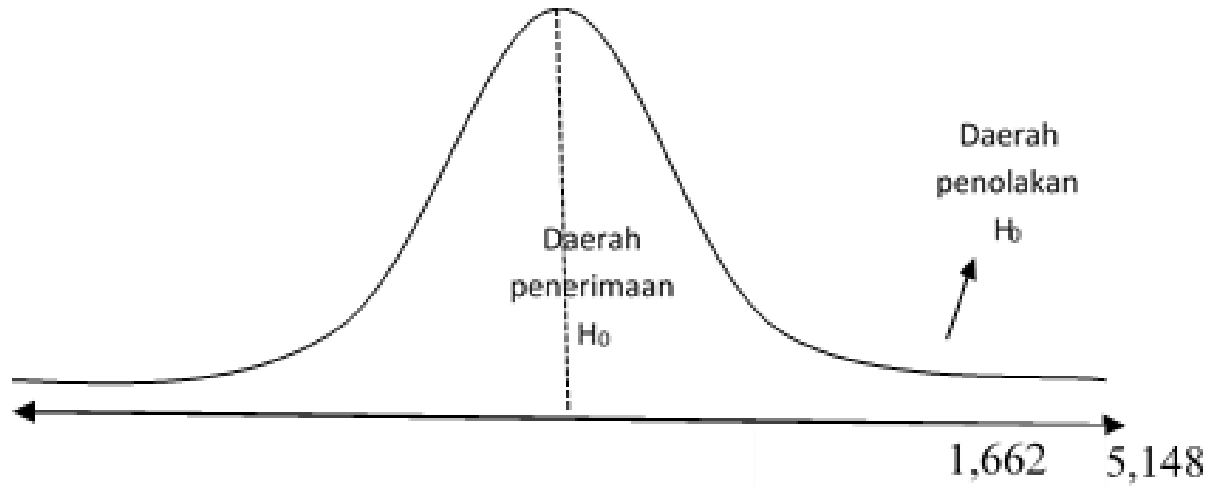

Gambar 4.

Daerah Penerimaan dan Penolakan $H_{0}$ Dengan Uji t untuk Variabel Jam Kerja $\left(\mathbf{X}_{\mathbf{3}}\right)$

Pengaruh Modal, Teknologi Informasi, dan Jam Kerja Terhadap Pendapatan Umkm Sektor Perdagangan di Denpasar Timur, Ida Ayu Asri Mahayuni dan Anak Agung Bagus Putu Widanta 
Berdasarkan hasil pengujian diperoleh nilai $t_{\text {hitung }} 5,148>1,662$ dan tingkat signifikansi sebesar $0,000<0,05$ berarti bahwa variabel jam kerja secara parsial berpengaruh positif dan signifikan terhadap pendapatan pelaku UMKM sektor perdagangan di Kecamatan Denpasar Timur. Nilai $\beta 3$ sebesar 0,320 menunjukkan bahwa jika jam kerja $\left(\mathrm{X}_{3}\right)$ bertambah 1 jam dan variabel bebas lainnya dianggap konstan maka pendapatan pelaku UMKM akan bertambah sebesar 0,320 rupiah. Teori ini didukung oleh penelitian yang dilakukan oleh Anik (2003) yang menyatakan bahwa semakin tinggi jam kerja yang digunakan, maka semakin tinggi pula pendapatan pekerja yang akan diperoleh. Dance Amnesi (2013), Triarya Nugraha (2013) dan Meta Trisnawati (2013) menyatakan jam kerja berpengaruh positif terhadap peningkatan pendapatan. Persamaan dalam penelitian ini menunjukkan penggunaan variabel jam kerja mempengaruhi pendapatan. Berdasarkan hal tersebut maka para pengusaha menambah jam kerja operasional UKM miliknya untuk berdagang, agar dapat meningkatkan pendapatan UKM.

Pada negara-negara berkembang usaha mikro kecil dan menengah (UMKM) memiliki peran serta yang sangat besar dalam pertumbuhan ekonomi negara tersebut. Dengan di dorong era digital yang semakin berkembang pesat saat ini seharusnya UMKM mampu tumbuh dengan baik memanfaatkan berbagai teknologi yang telah muncul. Penggunaan dan pemanfaatan teknologi pada era digital saat ini dapat menjadi peluang besar bagi para pelaku usaha mikro, kecil dan menengah (UMKM) dalam meningkatkan pendapatan dan pengembangan usahanya (Arseto, 2019). Penelitan ini berfokus pada hal-hal yang mempengaruhi pendapatan pelaku UMKM sektor perdagangan di Kecamatan Denpasar Timur.

Hal-hal yang diteliti yaitu modal, teknologi, dan jam kerja. Hasil dari penelitian ini menyatakan bahwa modal, teknologi, dan jam kerja memiliki pengaruh secara simultan terhadap pendapatan pelaku UMKM sektor perdagangan di Kecamatan Denpasar Timur. Variabel modal memiliki pengaruh secara positif terhadap pendapatan pelaku UMKM sektor perdagangan di Kecamatan Denpasar Timur. Semakin bertambahnya modal yang digunakan para pelaku UMKM maka mengakibatkan meningkatnya jumlah pendapatan pelaku UMKM sektor perdagangan di Kecamatan Denpasar Timur. Variabel teknologi memiliki pengaruh secara positif terhadap pendapatan pelaku UMKM sektor perdagangan di Kecamatan Denpasar Timur. Semakin bertambahnya pelaku UMKM yang menggunakan teknologi akan mengakibatkan meningkatnya jumlah pendapatan pelaku UMKM sektor perdagangan di Kecamatan Denpasar Timur. Variabel jam kerja memiliki pengaruh secara positif terhadap pendapatan pelaku UMKM sektor perdagangan di Kecamatan Denpasar Timur. Semakin bertambahnya jam kerja para pelaku UMKM maka mengakibatkan meningkatnya jumlah pendapatan pelaku UMKM sektor perdagangan di Kecamatan Denpasar Timur.

\section{SIMPULAN DAN SARAN}

Berdasarkan hasil analisis dan pembahasan yang telah diuraikan sebelumnya, maka dapat ditarik kesimpulan bahwa modal, teknologi informasi, dan jam kerja berpengaruh positif dan signifikan terhadap pendapatan pelaku UMKM sektor perdagangan di Kecamatan Denpasar Timur; Modal, teknologi informasi, dan jam kerja berpengaruh positif dan signifikan secara parsial terhadap pendapatan pelaku UMKM sektor perdagangan di Kecamatan Denpasar Timur.

Berdasarkan hasil penelitian dan simpulan diatas, maka dapat diajukan saran Kepada para pelaku UMKM agar lebih meningkatkan modal dan mengembangkan penggunaan teknologi, sebab dua hal ini memberikan pengaruh terhadap pendapatan usaha yang diperoleh. dan usahanya dengan memanfaatkan teknologi informasi yang semakin canggih untuk lebih meningkatkan pendapatan,

Pengaruh Modal, Teknologi Informasi, dan Jam Kerja Terhadap Pendapatan Umkm Sektor Perdagangan di 
selain itu mengenai bantuan permodalan para pelaku UMKM diharapkan dapat mengajukan bantuan secara pribadi atau individu kepada lembaga terkait, seperti koperasi atau lembaga pemberi bantuan lainnya. Serta untuk jam kerja pelaku UMKM lebih ditingkatkan misalnya dengan membuka lapangan pekerjaan untuk menambah pegawai untuk menambah jam kerja dalam meningkatkan pendapatan para pelaku UMKM. Kepada Pemerintah Kota Denpasar hendaknya memberikan lebih banyak dukungan kepada pelaku UMKM melalui pelatihan-pelatihan teknologi baru yang muncul pada era revolusi industri 4.0 sehingga pelaku usaha UMKM dapat bersaing secara kompetitif dipasar global saat ini. Pemerintah harus melakukan pembinaan berkelanjutan pada UMKM secara merata dan para pelaku usaha harus mampu memperbaharui perkembangan teknologi yang semakin tahun semakin berkembang. Dan untuk jam kerja pelaku UMKM lebih dimaksimalkan atau dengan cara menambah pegawai dengan cara shift. Serta bantuan modal sehingga pelaku UMKM di Kecamatan Denpasar Timur lebih mampu meningkatkan bahan penjualan untuk meningkatkan pendapatan atau usahausaha baru untuk meningkatkan pendapatan daerah.

\section{REFERENSI}

Amnesi., Dance. (2013). Analisis Faktor-Faktor Yang Berpengaruh Terhadap Pendapatan Perempuan Pada Keluarga Miskin Di Kelurahan Kapal

Ashari. (2006). Potensi Lembaga Keuangan Mikro (LKM) Dalam Pembangunan Ekonomi Pedesaan dan Kebijakan Pengembangannya, Analisis Kebijakan Pertanian, 4(2). Bogor: Pusat Analisis Sosial Ekonomi dan Kebijakan Pertanian

Kurniawan, Rahayu. (2011). Pengembangan Kopetensi Sumber Daya Manusian Dan Bantuan Modal Di Kabupaten Jepara. Skripsi. Universitas Negeri Semarang

Kurniawan., Jarot. (2016). Dilema Pendidikan dan Pendapatan di Kabupaten Grobogan. Jurnal Ekonomi Kuantitatif Terapan, 9(1). 59-67.

Pujari., D and Carbonell, P., A. Rodríguez-Escudero. (2004). Customer involvement in new service development: An examination of antecedents and out comes. Journal of Product Innovation Management 26(5),536-550

Rainer, R.K.,\& Cegielski, C. (2011). Introduction to Information Systems: Supporting and Transforming Business (3rded.). USA: John Wiley \& Sons

Reinartz, Werner J. dan Kumar, V. (2000). On the Profitability of Long-life Customers in a Noncontractual Setting: An Empirical Investigation and Implication for Marketing. Journal of Marketing. Vol 64. 17-35

Rimayanti, Ni Putu Sri; Sudarsana Arka. (2019). Analisis Faktor-Faktor yang Mempengaruhi Pendapatan Petani Garam di Kabupaten Karangasem. PIRAMIDA, 15(2), 213-240.

Samuelson, Paul A. (2008). Mikro Ekonomi. Jakarta: Erlangga

Sugiyono. 2017. Metode Penelitian Kuantitatif, kualitatif dan R\&D . Bandung: Alfabeta

Suharyadi, dan Purwanto. (2004). STATISTIKA: Untuk Ekonomi dan Keuangan Modern edisi 2 Buku 1. Jakarta: Salemba Empat.

Sukirno, Sadano. (2001). Pengantar Teori Mikro Ekonomi. Jakarta: Perusahan Raja Grafindo Persada.

Suparmoko, dan Irawan. (2003). Ekonomika Pembangunan, Edisi 6 . BPFE UGM: Jakarta

Surawiguna, T. J. (2010). Makalah E-Commerce. Jurusan Sistem Informasi STMIK Amikom. Halaman 5 - 15. Yogyakarta

Triarya Nugraha, Nyoman. (2013). Pengaruh Jam Kerja, Pengalaman Kerja Dan Pendidikan Terhadap Pendapatan Karyawan Pada Industri Bordir Di Kota Denpasar. Fakultas Ekonomi Universitas Udayana, Denpasar

Trisnawati , Meta. (2013).Pengaruh Modal Kerja, Tenaga Kerja, Jam Kerja Terhadap Pendapatan Nelayan Tradisional Di Nagari Koto Taratak Kecamatan Sutera Kabupaten Pesisir Selatan . Program Studi Pendidikan Ekonomi STKIP PGRI Sumatera Barat. Padang

Utari., Tri. (2014). Pengaruh Modal, Tingkat Pendidikan dan Teknologi terhadap Pendapatan Usaha Mikro Kecil dan Menengah (UMKM) di Kawasan Imam Bonjol Denpasar Barat . E-Jurnal Ekonomi Pembangunan Universitas Udayana. 3(12), 576 - 585

Pengaruh Modal, Teknologi Informasi, dan Jam Kerja Terhadap Pendapatan Umkm Sektor Perdagangan di Denpasar Timur, Ida Ayu Asri Mahayuni dan Anak Agung Bagus Putu Widanta 
Wiyasa., Ida Bagus Windu; Made Heny Urmila Dewi. (2017). Faktor - Faktor yang Mempengaruhi Pendapatan Melalui Curahan Jam Kerja Ibu Rumah Tangga Pengrajin Bambu di Kabupaten Bangli’. PIRAMIDA, 13(1), 27- 36.

Yasa, Artana; Sudarsana Arka. (2015). Pengaruh Pertumbuhan Ekonomi dan Disparitas Pendapatan Antardaerah Terhadap Kesejahteraan Masyarakat Provinsi Bali I. Jurnal Ekonomi Kuantitatif Terapan Vol 8 No 1 : $63-71$

Pengaruh Modal, Teknologi Informasi, dan Jam Kerja Terhadap Pendapatan Umkm Sektor Perdagangan di 